\title{
REGIONAL SECURITY IN THE MIDDLE EAST AREA IN THE PERIOD OF THE COLD WAR. TURKEY'S CONTRIBUTION TO REGIONAL SECURITY
}

\author{
G-N. DRAGNE
}

\section{Gabriela-Nicoleta DRAGNE}

PH-D, Faculty of History, History Field, Doctoral School of the University „Valahia” Târgoviște

Correspondence address: Eremia Grigorescu, no. 25, bl.45B, Sc.C, Ap.51, Ploiești, Prahova, Romania

Email: dragne.gabriela.nicoleta@gmail.com

\begin{abstract}
The alliance belt between Turkey, Iran, Pakistan and Iraq led to the creation of the political-military bloc nicknamed the Baghdad Pact, which aimed to limit Soviet expansionism to the warm seas and the Gulf and to ensure peace and security in the Middle East region.

Another trio of non-Arab states in the East: Turkey, Israel and Iran formed an influential military alliance in the late 1950s under the name of the Phantom Pact or the Peripheral Alliance in order to coordinate the activity of the three secret intelligence services, to coordinate their activities. express their anti-Soviet stance and maintain regional security. Equally, Turkey's involvement in regional affairs played an essential role. Today, the presence of the UN in the area, is facing a new danger of our times: terrorism.
\end{abstract}

KEYWORDS: military alliance, expansionism, regional security, terrorism.

\section{INTRODUCTION}

The Baghdad Pact, whose official name is "Treaty of the Middle East", was founded on February 24, 1955 between Iraq, Turkey, Pakistan, Iran and the United Kingdom, which acceded in 1958, renamed the Central Treaty Organization. or Cento after the Iraqi withdrawal on March 24, 1959. Another country in the Middle East with which Turkey had close traditional ties was Israel. Being the first Islamic country to recognize the Jewish state of Israel on March 18, 1949, less than a year after the official proclamation of Israel's independence, on May 14, 1948, Turkey's changing relations with Israel reached the climax of an alliance with Israel. trilateral security in 1958, nicknamed the "Peripheral Alliance". The two pacts are part of the international alliances of the western camp in the context of the Cold War.

\section{THE CHALLENGES OF THE ARABIC AND TRANSATLANTIC DIPLOMATION POLICIES}

During the rule of Menderes, Turkey initiated an assertive foreign policy in the region and to some extent renewed its importance in the Arab and Islamic world. Turkey's foreign 
policy in the Cold War years has generally focused on the Middle East's policy of working closely with the US and N.A.T.O. to limit any Soviet influence on Turkey.

Turkey's involvement in Middle East affairs in the 1950s was deliberately chosen by the Menderes government to break with Turkey the foreign policy of regional nonintervention in regional affairs and to resume its neglected relations with neighboring Islamic countries.

On the other hand, the Middle East, with strategic bases adjacent to the Soviet Union, vital communication links and significant oil wealth, has been a valuable region for Western interests. This is a common, open pact, as it was intended for other countries in the region establishing that Turkey and Pakistan will consult each other on international issues. Moreover, it is in fact a treaty of military alliance, under the auspices of art. 51 of the Charter of the United Nations ${ }^{1}$.Thus, the alliance belt created by Iran, Pakistan and Iraq was intended to limit Soviet expansionism to the warm seas and the Gulf, but the Middle East considered such cooperation to be an absurdity, as opposed to the ongoing battle against the colonial powers still present, and especially against Israel $^{2}$.

\section{DIPLOMATIC INTERFERENCES OF THE TWO CONTINENTS CONCERNING THE PACT}

The aim of the Baghdad Pact was ,to maintain peace and security in the Middle East region" ${ }^{3}$ and urged the Member States to ,,cooperate for their security and defense" and to refrain from any interference in the internal relations of the business" ${ }^{\prime}$.

„Open for accession to any member of the Arab League or for any other purpose actively pursuing security and peace in this region" ${ }^{5}$, the US alliance was designed to meet several goals $^{6}$. He appealed to its members for very different reasons, although the growing influence of the Soviet Union and Arab nationalism was widespread. By granting this treaty, Turkey has improved its relations with Western powers and Iraq has strengthened its position vis-à-vis Egypt ${ }^{7}$.

The 1950s is a troubled period and it is relatively difficult to succeed in granting everyone's interests in this area of conflict, the development of Arab nationalism and the rejection of colonial powers, hostility towards the countries that support Israel.

Thus, the U.S. he worked for the treaty as an unofficial observer and signed individual agreements with each of the countries in this Pact. Iran, in the early 1950s, was shaken by the turmoil of nationalist and communist circles, which demanded nationalization of oil. In Jordan, demonstrations are becoming more and more important, a state that has renounced and rejected the treaty, to the great satisfaction of Egypt and Saudi Arabia. The stages that the "Baghdad Pact" went through are:

- Turkey signed a Mutual Cooperation Pact with Pakistan in February54;

\footnotetext{
${ }^{1}$ Benoist-Méchin, Le Roi Saud ou l'Orient à l'heure des relèves, Paris, 1960, p.108.

${ }^{2}$ François Massoulié, Conflicts in the Middle East, translation by Radu Gâdei, BIC ALL Ed., Bucharest, 2003.

${ }^{3}$ The Pact of Baghdad, Preamble, p.9.

${ }^{4}$ Pact of mutual cooperation between the Kingdom of Iraq, the Republic of Turkey, the United Kingdom, the Dominion of Pakistan and the Kingdom of Iran of February 24, 1955, art. (1) and art. (3).

${ }^{5}$ Idem.

${ }^{6}$ Europe, the Middle East, London, 1960, p. 102.

${ }^{7}$ Waldemar J. Gallman, Iraq under General Nuri, Baltimore, 1964, pp. 21-65.
} 
Area signing a military agreement between Iraq and Turkey, and using the term "Baghdad Pact" on February 24, 1955. Iran, Pakistan and the United Kingdom join the Baghdad Pact;

- The establishment of a new republican regime, entails the withdrawal of Iraq from the alliance starting with February 24, 1955;

- The Baghdad Pact is renamed CENTO, starting August 19, 1959;

- Pakistan has been trying to get help from its allies in its war against India since 1965.

The United Nations Security Council adopted Resolution 211 on September 20, and the United States and the United Kingdom supported the O.N.U. by interrupting the supply of weapons for both belligerents.

In 1971, through a new war with India, Pakistan again unsuccessfully attempted to obtain Allied assistance. The US offers Pakistan limited military support, but not under CENTO. The new government of the Islamic Republic, Iran in 1979 withdrew the country from CENTO $^{8}$.

The first official step towards the conclusion of the Baghdad Pact was the treaty of April 4, 1954, between Turkey and Pakistan. The treaty was followed by US military aid agreements with Iraq (April 21) and Pakistan (May 10). Turkey and Iraq signed a mutual assistance pact on February 24, 1955. This was the Pact in Baghdad and it was open to all members of the Arab League and other states interested in peace and security in the Middle East. The United Kingdom also joined on April 5, 1955, and Pakistan and Iran in September and October. However, no other Arab state has followed the example of Iraqi Interior Minister Nuri to join the Western camp.

Syria's rejection of the pact led to the creation of a counter-alliance of Egypt, Syria and Saudi Arabia. In order to establish the Baghdad Pact, as well as to raise the prestige of Turkey, and especially in the face of Arab countries, the Americans put pressure on Pakistan to enter the Baghdad Pact ${ }^{9}$.

The meeting of the Pact Council in Baghdad was held on November 21-22, which established the form of organization of the Pact. Thus, the permanent Political Council is established "where each participant will have a permanent representative with the rank of ambassador, economic adviser and military adviser" ${ }^{10}$.

The British insisted on economic issues, and the US through Turkey insisted on the military side of the pact, because by providing even more armament and technicians, they could more easily subjugate these countries.

At first the American imperialists tried to achieve a political unity within the Arab countries, but they were struck by the English imperialism which sought to maintain its political and economic influence in this part of the world at all costs.

None of the Muslim countries except Iraq and Pakistan agreed to join the TurkishIraqi Pact. Thus, at the end of February 1955, the heads of the two governments, the Turkish and the Iraqi, signed the text of the treaty at the beginning of $\mathrm{March}^{11}$.

Here is what the attitude of the main Arab countries was, in relation to the TurkishIraqi pact:

\footnotetext{
${ }^{8}$ https://en.wikipedia.org/wiki/Baghdad_Pact.

${ }^{9}$ DAMFA, Turkey Fund 71, File 20/1955, Row 13.

${ }^{10}$ Idem.

${ }^{11}$ Ibidem, p. 4.
} 
- regarding Egypt, it started in its action, from the principle that, the Arab world must form a unity separate from any blocs linked to Western countries and even America and not make any alliance with any country that is linked to such blocs ${ }^{12}$.

- $\quad$ in the beginning, Syria has somewhat adopted an expectant attitude;

- Saudi Arabia opposed the Turkish-Iraqi pact and later agreed with Egypt's proposal to conclude a political, economic and military agreement with all Arab countries ${ }^{13}$.

As for the attitude of the other Arab countries, it was quite opposite to the attitude adopted by the three states above, as follows:

IstanPakistan was already linked to Turkey by the Ankara-Karaci pact and sooner or later would join the Turk-Iraqi pact. Libanon had a somewhat favorable position on the Turkish-Iraqi pact and the position of Trans-Jordan was about the same as Lebanon and its entry into the Turkish-Iraqi pact did not bring any essential change within the Arab world, so it was kept in reserve.

Iran did not show itself to be quite favorable to the Turkish-Iraqi pact, but it also did not take a very unfavorable attitude. On the one hand, the British who dominated this part of the world sought to maintain their economic positions and political influence in these countries, and American imperialism was constantly seeking to eliminate English imperialism from the Middle East market.

The stage of the Turkish-Iraqi pact was quite shaky, even with the accession of England to it and probably soon to be Pakistan.

As regards the accession of Iran, it will renounce the policy of neutrality, and on October 10, 1955, Iran officially announced the accession to the Turkish-Iraqi pact ${ }^{14}$.

The fact that Turkey has given such a great popularity to the accession of Iran, had two main objectives: the attempt of the Turkish government to gain its prestige in front of the Americans and to obtain new loans with which they hoped to emerge from the economic and political bankruptcy, which was at that time.

\section{CONCLUSIONS}

The formation of the Baghdad Pact greatly destabilizes the region and disrupts interArab relations. By linking an Arab country to a Western power, the pact contravenes the panArab ambitions of which Nasser is the spokesperson. He becomes a champion of the opposition to the pact.

Saudi Arabia ranks on the Egyptian side. The same was true for Syria. Lebanon, in the end, finally rejected the pact. Jordan was facing a strong popular opposition that forced him to give up accession. The Arab world was divided on the issue of the pact. In addition, the pact reinforces the Arab nationalist sentiment and paradoxically, the influence of the USSR in the region.

The Baghdad Pact cannot be considered a success, the goals set out being far from being achieved. It, evolving into more economic than military cooperation, taking the name CENTO, the Central Treaty Organization on August 21 of the same year. The Iranian revolution of 1979 and the withdrawal of Iran marks the end of the alliance.

\section{BIBLIOGRAPHY}

\footnotetext{
${ }^{12}$ Ibidem, p. 6.

${ }^{13}$ Idem, p. 10 .

${ }^{14}$ Ibidem, p. 16.
} 
REGIONAL SECURITY IN THE MIDDLE EAST AREA IN THE PERIOD OF THE COLD WAR. TURKEY'S CONTRIBUTION TO REGIONAL SECURITY

Benoist-Méchin, The King Saud or the East at the time of relief, Paris, 1960

François Massoulié, Conflicts in the Middle East, translation by Radu Gâdei, BIC ALL ed., Bucharest, 2003.

Waldemar J. Gallman, Iraq under General Nuri, Baltimore, 1964.

Diplomatic Archive of the Ministry of Foreign Affairs, Turkey Fund 71, File 20/1955.

Pact of mutual cooperation between the Kingdom of Iraq, the Republic of Turkey, the United Kingdom, the Dominion of Pakistan and the Kingdom of Iran of February 24, 1955, art. (1) and art. (3).

https://en.wikipedia.org/wiki/Baghdad_Pact. 